\title{
Randomised controlled trial of L-carnitine as a nutritional supplement in preterm infants
}

\author{
G J Shortland, J H Walter, C Stroud, P J Fleming, B D Speidel, N Marlow
}

\begin{abstract}
Aims-To evaluate the effect of L-carnitine supplementation $(25 \mathrm{mg} / \mathrm{kg} / \mathrm{d})$ on the growth and incidence of hypoglycaemia in preterm infants.

Methods-A double blind, placebo controlled randomised trial, stratified for gestational age, was conducted of 86 preterm infants between 28 and 34 gestational weeks. The median gestational ages in the carnitine group and placebo groups were 30.7 weeks (range 28.0 to 33.6 ) and 31.4 weeks (range 28.0 to 33.9 ), respectively. The median birthweights were $1.557 \mathrm{~kg}$ (range 0.944 to 2.275 ) and $1.645 \mathrm{~kg}$ (range 0.885 to 2.545 ), respectively.
\end{abstract}

Results-Mean plasma free carnitine concentrations were below values for normal term infants in both groups on day 1 (carnitine group $44.8 \mu \mathrm{mol} / 1$, placebo group $25.5 \mu \mathrm{mol} / \mathrm{l})$ in the placebo group on day 7 (50.7 $\mu \mathrm{mol} / \mathrm{l})$, but in neither group on days 14 and 28. Total, free, and acylcarnitine concentrations were significantly increased in both urine and blood in the L-carnitine group. There was no significant difference between the placebo and carnitine supplemented groups in growth rate, as assessed by weight, length, skinfold thickness and head circumference measurements, or in the incidence of episodes of hypoglycaemia.

Conclusion-The addition of carnitine as a nutritional supplement at a dose of $25 \mathrm{mg} / \mathrm{kg} /$ day did not improve growth in our group of preterm infants nor protect them from episodes of hypoglycaemia. (Arch Dis Child Fetal Neonatal Ed 1998;78:F185-F188)

Keywords: plasma carnitine; hypoglycaemia; nutritional supplements

The ability to use substrates other than glucose is an important postnatal adaptation in neonates. Maternal glucose is the main fuel for the fetus but after delivery this source of energy ceases abruptly. Hepatic glycogen, synthesised primarily in the latter part of gestation, is rap-

Table 1 Description of stratified subgroups and numbers and sex of infants in each subgroup

\begin{tabular}{|c|c|c|c|c|c|}
\hline \multirow[b]{2}{*}{ Group } & \multirow[b]{2}{*}{ Gestation at birth } & \multicolumn{2}{|c|}{ Placebo } & \multicolumn{2}{|c|}{ Carnitine } \\
\hline & & No & Male & No & Male \\
\hline 1 & 28 weeks -29 weeks, 6 days & 14 & 8 & 16 & 5 \\
\hline 2 & 30 weeks -31 weeks, 6 days & 16 & 12 & 13 & 8 \\
\hline \multirow[t]{2}{*}{3} & 32 weeks -33 weeks, 6 days & 13 & 7 & 14 & 8 \\
\hline & All groups & 43 & 27 & 43 & 21 \\
\hline
\end{tabular}

idly depleted within the first 24 hours after birth and the oxidation of fat then becomes the major source of energy for the infant. Falling concentrations of insulin and an increase in glucagon and catecholamines mobilise free fatty acids from triglyceride stores in adipose tissue. Fatty acids are then oxidised within mitochondria to produce reducing equivalents for the respiratory chain, together with ketone bodies, which act as an alternative energy source for the brain and heart. ${ }^{1}$

Carnitine has an essential role in this process of fat metabolism as it is required for the transport of long chain fatty acids into mitochondria where $\beta$ oxidation occurs. It can also fulfil a detoxifying role by forming and exporting acylcarnitine esters of acyl-CoA molecules that accumulate within the mitochondria. Plasma and tissue concentrations of carnitine are low in newborn infants compared with those found in older children. ${ }^{2}$ This may be due to immaturity of synthetic pathways ${ }^{3}$ or reflect a lower renal threshold. ${ }^{4}$ Carnitine is found in both human milk (abstract presented to the 16th International Congress of Pediatrics, Barcelona, 1980) and infant formulas manufactured from cows' milk, ${ }^{5}$ but is absent from soya milk ${ }^{6}$ and most parenteral feeding formulations. In term infants a major deficiency of carnitine is unlikely provided oral feeding is established. Preterm infants may be at more risk of deficiency because of immaturity of synthetic pathways and renal mechanisms, together with delayed oral feeding.

Any reduction in the ability of preterm infants to oxidise fats might lead to a reduction in all processes that require energy, with an increased risk of hypoglycaemia, hypothermia (from inadequate heat production in brown adipose tissue), respiratory distress and infection. As growth is an energy requiring process, a prolonged reduction in energy production may adversely affect postnatal growth.

Although there have been few studies on the short term metabolic consequences of giving additional carnitine in newborn infants ${ }^{78}$ and observation of weight gain during the first two weeks of life, ${ }^{9}$ we are not aware of any prospective placebo controlled randomised trials of the effect of carnitine supplementation on growth in preterm infants.

The objectives of this trial were to determine whether supplementation with L-carnitine would reduce the incidence of hypoglycaemia and improve postnatal growth in preterm infants of less than 34 weeks of gestation.

\section{Methods}

The study was a randomised double blind, placebo controlled trial in preterm infants of 28 
Table 2 Results of urinary total, free, and acylcarnitine ( $\mu$ mol/l) in placebo and carnitine supplemented groups at days 1,4,7 and 10 after birth

\begin{tabular}{|c|c|c|c|c|}
\hline & \multicolumn{2}{|c|}{ Infants receiving carnitine } & \multicolumn{2}{|c|}{ Infants receiving placebo } \\
\hline & $\begin{array}{l}\text { Number } \\
\text { of infants }\end{array}$ & $\begin{array}{l}\text { Mean (SD) } \\
\text { concentration }\end{array}$ & $\begin{array}{l}\text { Number } \\
\text { of infants }\end{array}$ & $\begin{array}{l}\text { Mean (SD) } \\
\text { concentration }\end{array}$ \\
\hline \multicolumn{5}{|c|}{ Total carnitine: } \\
\hline Day 1 & 36 & $44.8(24.2)$ & 41 & $25.5(16.0)$ \\
\hline Day 4 & 39 & $1270(1283)^{\star}$ & 34 & $50.7(141)$ \\
\hline Day 7 & 33 & $985(604)^{\star}$ & 35 & $39.8(43.20)$ \\
\hline Day 10 & 38 & $1642(1324)^{\star}$ & 38 & $59.7(67.4)$ \\
\hline \multicolumn{5}{|c|}{ Free carnitine: } \\
\hline Day 1 & 36 & $26.7(20.2)$ & 41 & $13.6(11.2)$ \\
\hline Day 4 & 39 & $1085(1156)^{\star}$ & 34 & $17.2(37.4)$ \\
\hline Day 7 & 33 & $813(489)^{\star}$ & 35 & $25.6(34.4)$ \\
\hline Day 10 & 38 & $1266(951)^{\star}$ & 38 & $45.0(54.3)$ \\
\hline \multicolumn{5}{|c|}{ Acylcarnitines: } \\
\hline Day 1 & 36 & $17.4(14.0)$ & 41 & $12.9(12.0)$ \\
\hline Day 4 & 39 & $191(205)^{\star}$ & 34 & $12.7(21.5)$ \\
\hline Day 7 & 33 & $173(166)^{\star}$ & 35 & $14.3(12.2)$ \\
\hline Day 10 & 38 & $386(450)^{\star}$ & 38 & $19.9(23.2)$ \\
\hline
\end{tabular}

$\star$ Denotes significant difference, $\mathrm{p}<0.05$, between concentrations in carnitine and placebo groups.

Table 3 Results of plasma total, free, and acylcarnitine ( $\mu m o l / l)$ in placebo and carnitine supplemented groups at days 1,7,14 and 28 after birth

\begin{tabular}{|c|c|c|c|c|}
\hline & \multicolumn{2}{|c|}{ Infants receiving carnitine } & \multicolumn{2}{|c|}{ Infants receiving placebo } \\
\hline & $\begin{array}{l}\text { Number } \\
\text { of infants }\end{array}$ & $\begin{array}{l}\text { Mean }(S D) \\
\text { concentration }\end{array}$ & $\begin{array}{l}\text { Number } \\
\text { of infants }\end{array}$ & $\begin{array}{l}\text { Mean }(S D) \\
\text { concentration }\end{array}$ \\
\hline \multicolumn{5}{|c|}{ Total carnitine: } \\
\hline Day 1 & 32 & $25.8(12.8)$ & 33 & $24.3(12.4)$ \\
\hline Day 7 & 32 & $160(127)^{\star}$ & 33 & $33.0(33.0)$ \\
\hline Day 14 & 31 & $111(48.5)^{\star}$ & 38 & $44.9(86.4)$ \\
\hline Day 28 & 21 & $104(30.9)^{\star}$ & 25 & $44.6(17.7)$ \\
\hline \multicolumn{5}{|c|}{ Free carnitine: } \\
\hline Day 1 & 37 & $15.8(7.2)$ & 42 & $16.0(9.8)$ \\
\hline Day 7 & 36 & $102(81.8)^{\star}$ & 40 & $19.1(15.6)$ \\
\hline Day 14 & 33 & $69.0(29.0)^{\star}$ & 37 & $34.2(74.7)$ \\
\hline Day 28 & 22 & $64.0(16.4)^{\star}$ & 29 & $32.8(14.5)$ \\
\hline \multicolumn{5}{|c|}{ Acylcarnitines: } \\
\hline Day 1 & 28 & $9.8(10.4)$ & 33 & $11.5(13.0)$ \\
\hline Day 7 & 33 & $57.0(37.0)^{\star}$ & 34 & $11.0(8.3)$ \\
\hline Day 14 & 30 & $44.6(25.9)^{\star}$ & 37 & $14.1(14.0)$ \\
\hline Day 28 & 20 & $41.2(15.1)^{\star}$ & 27 & $13.2(19.7)$ \\
\hline
\end{tabular}

${ }^{\star}$ Denotes significant difference, $\mathrm{p}<0.05$, between concentrations in carnitine and placebo groups.

weeks to 34 weeks 6 days' gestation, admitted to the neonatal intensive care units at $\mathrm{St}$ Michael's Hospital and Southmead Hospitals, Bristol, UK, over 21 months. Infants were included if they initially required intravenous fluids and had a birthweight between the 10th and 90th centiles for gestational age according to the standard centile charts of Gairdner and Pearson. ${ }^{10}$ Multiple births, infants with severe birth asphyxia (Apgar score less than or equal to 3 at five minutes), a persistent metabolic acidosis ( $\mathrm{pH}$ less than 7.2 for more than four hours), or a recognised congenital abnormality were excluded from the study. Ethical approval was obtained from the local research ethics committees. On recruitment infants were stratified into one of three groups, according to gestation (table 1) and allocated to receive either L-carnitine or placebo according to a predetermined random code. The placebo and L-carnitine preparations were of identical appearance and the investigators and staff caring for the infants were unaware of the allocation until after completion of the study. After recruitment and within 72 hours of birth, infants were given L-carnitine $25 \mathrm{mg} / \mathrm{kg} /$ day or placebo daily until the equivalent of 40 weeks of gestation. An intravenous preparation was used until oral feeds were established. The total daily dose was reviewed on a weekly basis and adjusted according to weight. L-carnitine was supplied by Sigma-Tau, Rome, Italy and the randomisation codes for patients arranged by Advisory Services (Clinical and General) Ltd., Harley Street London.

Infants were fed according to the unit policy at the time of the study. Carbohydrate and fat supplements (Duocal, Scientific Hospital Supplies) were given to infants receiving breast milk. Preterm infants not breastfed received a preterm milk formula (Prematalac, Wyeth) until they reached $1800 \mathrm{~g}$ after which they were weaned on to a standard infant milk formula.

Measurements of weight, length, skinfold thickness and occipito-frontal head circumference were recorded on the first study day and subsequently on days 4,7 , and 10 after birth. Subsequently, measurements were performed twice weekly until either the infants reached the equivalent of 40 weeks of gestation or were discharged from hospital and then at 1, 3, and 6 months after the expected date of delivery (EDD). Weight was measured using standard electronic scales (Seca) to the nearest $5 \mathrm{~g}$, crown-heel length using a Holtain neonatometer (Holtain, Crymych, Dyfed, Wales) or by paper tape measure when infants could not be removed from an incubator, left mid thigh skinfold thickness using Holtain skinfold callipers and occipito-frontal circumference using a paper tape measure to the nearest $(1 \mathrm{~mm})$. All measurements were taken either by GJS or CS.

Growth velocity by weight, occipito-frontal head circumference, length and skinfold thickness were assessed. In each infant growth velocity, for all parameters, was assessed for the following periods: (i) every two weeks while the infants were inpatients; (ii) from discharge to one month after the EDD; (iii) from 1 month to 3 months after EDD; and (iv) from 3 months to 6 months after EDD.

Urine was collected on entering the study (before receiving either carnitine or placebo), and on days 4, 7, and 10 after birth. Plasma samples were collected on entering the study and on days 1, 7, 14 and 28. Samples were stored at $-20^{\circ} \mathrm{C}$ until analysed. Total, free, and acyl-carnitine concentrations in urine and

Table 4 Details of weight gain (g/day) for previous two week periods while an inpatient

\begin{tabular}{|c|c|c|c|c|c|c|c|}
\hline \multicolumn{3}{|c|}{ Placebo group } & \multicolumn{3}{|c|}{ Carnitine group } & \multirow[b]{2}{*}{$\begin{array}{l}\text { Mean difference between } \\
\text { two groups }\end{array}$} & \multirow[b]{2}{*}{$\begin{array}{l}\text { Standard } \\
\text { error }\end{array}$} \\
\hline $\begin{array}{l}\text { Age } \\
\text { (weeks) }\end{array}$ & $\begin{array}{l}\text { No of } \\
\text { infants }\end{array}$ & $\begin{array}{l}\text { Mean weight gain (SD) for the } \\
\text { previous two weeks }\end{array}$ & $\begin{array}{l}\text { Age } \\
\text { (weeks) }\end{array}$ & $\begin{array}{l}\text { No of } \\
\text { infants }\end{array}$ & $\begin{array}{l}\text { Mean weight gain (SD) for the } \\
\text { previous two weeks }\end{array}$ & & \\
\hline 2 & 42 & $1.0(6.3)$ & 2 & 41 & $0.5(7.4)$ & 0.5 & 9.7 \\
\hline 4 & 37 & $22.3(10.8)$ & 4 & 32 & $23.1(6.5)$ & 0.8 & 12.6 \\
\hline 6 & 18 & $24.6(7.9)$ & 6 & 16 & $27.7(9.5)$ & 3.1 & 12.3 \\
\hline 8 & 11 & $27.6(6.1)$ & 8 & 10 & $23.3(9.1)$ & 4.3 & 10.9 \\
\hline
\end{tabular}


Table 5 Details of weight gain (g/day) for the period from discharge to one month after the EDD (1), from 1 to 3 months after EDD (2), and 3 to 6 months after EDD (3)

\begin{tabular}{|c|c|c|c|c|c|c|c|}
\hline \multicolumn{3}{|c|}{ Placebo group } & \multicolumn{3}{|c|}{ Carnitine group } & \multirow[b]{2}{*}{$\begin{array}{l}\text { Mean difference between } \\
\text { two groups }\end{array}$} & \multirow[b]{2}{*}{ Standard error } \\
\hline Age & $\begin{array}{l}\text { No of } \\
\text { infants }\end{array}$ & $\begin{array}{l}\text { Mean weight gain } \\
\text { (SD) }\end{array}$ & Age & $\begin{array}{l}\text { No of } \\
\text { infants }\end{array}$ & $\begin{array}{l}\text { Mean weight gain } \\
\text { (SD) }\end{array}$ & & \\
\hline 1 & 42 & $34.6(9.5)$ & 1 & 41 & $35.4(11.8)$ & 0.8 & 15.1 \\
\hline 2 & 39 & $25.6(7.8)$ & 2 & 39 & $26.6(8.3)$ & 1.0 & 11.4 \\
\hline 3 & 41 & $19.9(16.7)$ & 3 & 40 & $19.4(6.6)$ & 0.5 & 17 \\
\hline
\end{tabular}

plasma were measured using a radioenzymatic method based on the method originally described by Cederbald and Liustedt. ${ }^{11}$ After the measurement of free carnitine in blood or urine, short and long chain esters of carnitine were hydrolysed to yield free carnitine which was then measured again to give the total carnitine. Acylcarnitine was then calculated from total carnitine less free carnitine.

Blood sugars were measured on capillary or venous blood according to the unit standard policy with the frequency of monitoring increased (to every 3 to 6 hours) during periods when infants required intensive care. Glucose measurements were made, at the time of the study, in most cases using glucose oxidase reagent sticks and rechecked using measurements of true blood glucose.

Statistical analysis was performed using Student's $t$ test for parametric analysis and the Wilcoxon signed rank test for non-parametric analysis. A significant difference was taken as a $\mathrm{p}$ value of $<0.05$. Means are shown with (1) standard deviation.

\section{Results}

Eighty six infants fulfilled the inclusion criteria. The parents of one infant withdrew consent after recruitment, and one infant had a nasopharyngeal teratoma. One infant died at 7 days of age from an intraventricular haemorrhage (L-carnitine, group 1) and one infant died after completing the medication (placebo, group 2) from sudden infant death syndrome.

The study and placebo groups, each of 43 infants, did not differ significantly in gestation, birthweight, sex, or incidence of intrapartum asphyxia (as assessed by cord blood $\mathrm{pH}$ or Apgar scores). The median gestational ages in the carnitine group and placebo groups were 30.7 weeks (range 28.0 to 33.6 ) and 31.4 weeks

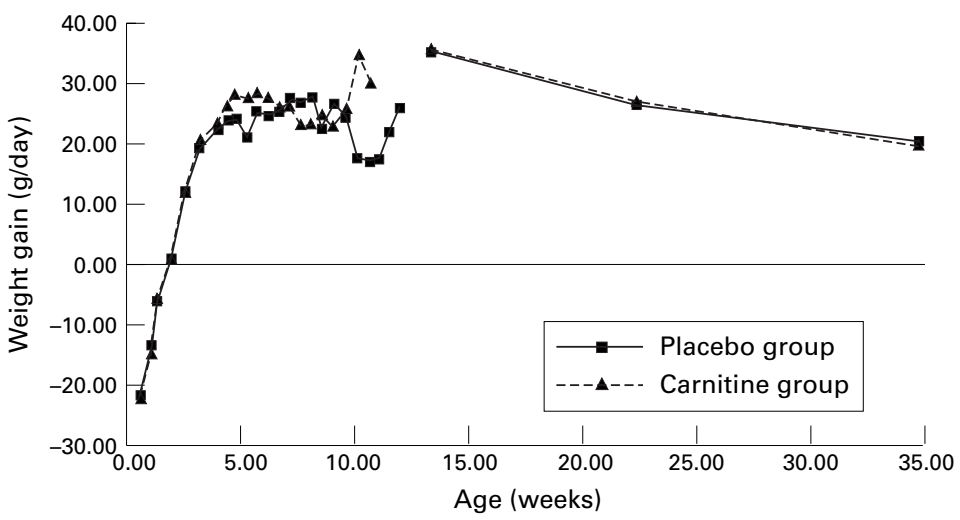

Figure 1 Weight velocity for all infants shown as weight gain (g) per day measured every two weeks from the beginning of the study during hospital stay, from discharge to 1 month after the EDD, from one to three months after $E D D$, and from one to six months after the EDD. (range 28.0 to 33.9 ), respectively. The median birthweights were $1.557 \mathrm{~kg}$ (range 0.944 to 2.275 ) and $1.645 \mathrm{~kg}$ (range 0.885 to 2.545 ), respectively.

Total, free, and acylcarnitine concentrations in the urine were similar in both study groups on trial entry. On subsequent days substantial increases were observed in all these parameters in the L-carnitine group. (table 2). Smaller but clinically significant increases in plasma total, free, and acylcarnitine were seen in the L-carnitine group (table 3).

The results for growth in weight are summarised in tables 4 and 5 and fig 1 . The measurements for occipito-frontal head circumference, length, and skinfold thickness were similarly analysed and showed no significant differences between the supplemented and placebo group, using either parametric or non-parametric tests. Data, when analysed by subgroups, also failed to show any significant differences.

During the first seven days of life there was no significant difference between the placebo and L-carnitine groups in terms of the number of episodes of blood glucose at less than 3 $\mathrm{mmol} / \mathrm{l}$ in each stratified group. The overall number of episodes was 33 in the placebo group and 39 in the carnitine group.

\section{Discussion}

The central role of carnitine in energy production has led to considerable interest in its role in preterm infants. The generation of substrate from fat oxidation for ATP synthesis by the respiratory chain allows for a reduction both in glucose oxidation in tissues where glucose is not an essential fuel and in amino acid catabolism for gluconeogenesis and energy production. Any reduction in the ability of the preterm infant to oxidise fats may, in theory, lead to a reduction in all processes that require energy with an increased risk of hypoglycaemia, hypothermia (from inadequate heat production in brown adipose tissue), respiratory distress and infection. In our study there was no significant difference in the number of episodes of blood sugar $<3 \mathrm{mmol} / \mathrm{l}$ between the supplemented group and those given placebo. The choice of $<3 \mathrm{mmol} / \mathrm{l}$ as the significant cutoff point recognises that hypoglycaemia is a continuum. Its biological effects vary according to the availability of other fuels and other compounding clinical problems. The visual inspection of reagent test strips may also be imprecise between 0 and $3 \mathrm{mmol} / 1$. A prolonged reduction in energy production may induce poor postnatal growth.

The limited ability of preterm infants to make endogenous carnitine and to obtain adequate exogenous supplies from intravenous 
fluid has led to concerns that low tissue carnitine concentrations may have a detrimental effect on these babies. Preterm infants have a lower concentration of ketone bodies, suggesting that lipolysis and/or ketogenesis may be limited. ${ }^{12}$

In our study there was no difference in any of the growth parameters between the supplemented group and those given placebo.

Plasma concentrations of free carnitine were consistently lower in our placebo group than those previously reported in older infants. ${ }^{13}$ They were similar to those previously reported in other preterm infants. ${ }^{14} 15$ Symptoms clear up completely in children with primary carnitine deficiency, who have clinical manifestations of impaired fatty acid oxidation, when the tissue carnitine concentration is raised to as little as $5 \%$ of normal. ${ }^{16}$ The values we observed in the placebo group were similar to those reported when preterm infants were fed on carnitine free intravenous feeding for more than two weeks. ${ }^{17}$ The absence of any increase in growth or reduction in hypoglycaemia in our carnitine supplemented group suggests that tissue values of carnitine in the placebo group were not sufficiently low to have a clinically significant effect on energy metabolism.

The dose of carnitine used in our study increased urine and plasma concentrations well above normal childhood and adult values. Acylcarnitine concentrations were at least double those of the placebo group, indicating that carnitine was entering cells to form acylcarnitine esters and not simply being excreted as free urinary carnitine. Although we were unable to measure tissue carnitine concentrations the high concentrations of plasma and urine carnitine suggest that a dose of carnitine greater than the $25 \mathrm{mg} / \mathrm{kg} /$ day is unlikely to have any additional metabolic effect.

We conclude that the addition of carnitine as a nutritional supplement does not increase growth in preterm infants nor protect them from episodes of hypoglycaemia. A smaller defined group of infants may still benefit from carnitine supplementation, such as those receiving prolonged parenteral nutrition, those fed on soya based formula, those on a semi-elemental diet or growth retarded infants (who were excluded from this study).

We thank Dr J Holton and Carol Green of Southmead Hospital, Southmead, Bristol for their help with the measurement of plasma carnitine. These studies were supported by a grant from plasma carnitine. These studies were supported by a grant from
Action Research (S/P/1900) and Advisory Services, London.

1 Bourgneres PF, Zemmel C, Ferre P, Bier DM. Ketone body transport in the human neonate and infant. $\mathcal{f}$ Clin Invest transport in the

2 Shenai JP, Borum PR, Mohan P, Donlery SC. Carnitine status at birth of newborn infants of varying gestation. Pediat ric Res 1983;17:579-82.

3 Olson AL, Rebouche CJ. y-Butyrobetaine hydroxylase activity is not rate limiting for carnitine biosynthesis in the human infant. F Nutr 1987;117:1024-31.

4 Melegh B, Szucs L, Kerner J, et al. Changes of plasma free amino acids and renal clearence of carnitine in preterm infants during L-carnitine supplemented human milk feeding. F Pediatr Gastroenterol Nutr 1988:7:424-9.

5 Rubaltelli FF, Orzali A, Rinaldo P, Donzelli F, Carnielli V. Carnitine and the premature. Biol Neonate 1987;52 (suppl 1):65-77.

6 Warshaw J B, Curry E. Comparison of serum carnitine and ketone body concentrations in breast and in formula-fed ketone body concentrations in breast and
newborn infants. F Pediatr 1980;97:122-5.

7 Orzali A, Donzelli F, Enzi G, Rualtell FF. Effect of carnitine on lipid metabolism in the newborn. Biol Neonate 1983;43:186-90.

8 Melegh B, Kerner J, Sandor A, Vinceller M, Kispal G. Effects of oral L-cariniture supplementations in low birth weight premature infants maintained on humam milk. Biol Neonate 1987;51:185-93.

9 Bonner CM, DeBrie KL, Hug G, Landrigan E, Taylor BJ. Effects of parenteral L-carnitine supplementation on fat metabolism and nutrition in premature neonates. $\mathcal{F}$ Pediatr 1995;126:287-92.

10 Gairdner D, Pearson J. Growth and Development Record (Preterm-2 years). Ware: Castlemead Publications, 1988.

11 Cederblad G., Lindstedt S. A method for the determination of carnitine in the picomol range. Clin Chim Acta of carnitine in

12 Hawdon J.M., Ward Platt M P, Aynsley-Green A. Patterns of metabolic adaptation for preterm and term infants in the first neonatal week. Arch Dis Child 1992;67:357-65.

13 Battistella PA, Vergani L, Angelini C. Tissue levels of carnitine in human growth. Perspect Inherited Metabol Dis 1979;3:151-62.

14 Cederblad G, Svenningsen N. Plasma carnitine and breast milk carnitine intake in premature infants. 7 Pediatr Gastroenterol Nutr 1986;5:616-21.

15 Rovamo LM, Salmenpera L, Arjomaa P, Raivio KO. Carnitine during prolonged breast feeding. Pediatr Res 1986;20:806-9.

16 Treem WR, Stanley CA, Finegold DN, et al. Primary carnitine deficiency due to failure of carnitine transport in kidney, muscle and fibroblasts. N Engl F Med 1988;319:331-6.

17 Schiff D, Chan G, Seccombe D, Hahn P. Plasma carntine levels during intravenous feeding of the neonate. $\mathcal{F}$ Pediatr 1979;95:1043-10 